
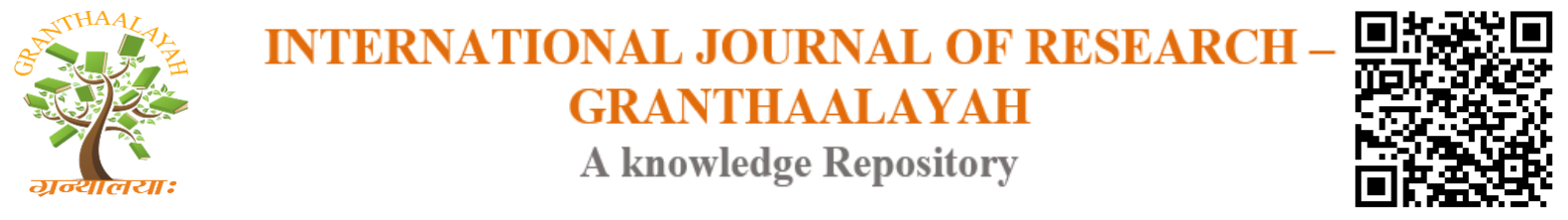

Management

\title{
AGRICULTURE AS A RECIPE FOR AN OIL DEPENDENT ECONOMY: NIGERIA EXPERIENCE
}

\author{
Ajibola, Joseph Olusegun $*^{1}$ \\ (Ph.D., FCIB, FICA, FERP, ACTI, LLB, BL) \\ ${ }^{* 1}$ Department of Economics, Babcock University, Ilishan-Remo, Ogun State, NIGERIA
}

DOI: https://doi.org/10.29121/granthaalayah.v4.i8.2016.2575

\section{ABSTRACT}

Nigeria has a great potential to build a diversified sustainable and prosperous economy. Conversely, Nigeria has economic problems, her poverty situation is alarming though it records an impressive rate of economic growth which grew at an average $7.6 \%$ between 2003 and 2010(World Bank 2011), but this did not lead to sustainable development. This research work presents the position of agricultural sector as a dominant tool for reviving the Nigerian Economy from being monoculture. The paradox of growth in the face of poverty and inequality conflicts rational economic and social theories as well as historical trends showing vividly the structural disequilibrium in the Nigerian economy which has sustained the key productive and highly employable sectors below potential while supporting consumerism and rent-seeking sector which made laudable growth rate stranded at top of the pyramid not getting to both middle and bottom where the larger percentage of the populace can be better off. Among the recommendations made was that government should give immediate attention to the procurement and subsiding of farm tools for easy development of the sector. Also, Irrigation system should be encouraged for better efficiency in production process. More so, government should establish Companies that will convert agricultural primary product to nonperishable goods which stabilize the market price of farm product and motivate labour force to remain in the sector.

Keywords:

Agriculture Sector, Nigerian Economy, Oil Sector, Monoculture Economy.

Cite This Article: Ajibola, Joseph Olusegun, "AGRICULTURE AS A RECIPE FOR AN OIL DEPENDENT ECONOMY: NIGERIA EXPERIENCE” International Journal of Research Granthaalayah, Vol. 4, No. 8 (2016): 157-167.

\section{INTRODUCTION}

Oil dominates the Nigerian economy, rising from $29 \%$ of gross domestic product (GDP) in 1980 to $52 \%$ in 2005. Oil and gas now contribute about $99 \%$ of exports and nearly $85 \%$ of government revenues, although their contribution to employment is estimated to be only $4 \%$ 
CBN (2013). Agriculture, the second largest sector, fell from $48 \%$ of GDP in 1970 to $20.6 \%$ in 1980 and was only $23.3 \%$ of GDP in 2005. Agricultural sectors are negligible and represent about $0.2 \%$ of total exports. Nevertheless, an estimated $60 \%$ of Nigerians are employed in the rural sector. Manufacturing and services represented $4.6 \%$ and $19.9 \%$ of GDP, respectively, in 2005. Most economic activity is therefore in primary production with limited value added through processing and agro-business. Since 1999, Nigerian GDP has grown at an average annual rate of $3.5 \%$. While it stood at $6.0 \%$ growth rate from 2004-2014.

The long-term potential growth rate has been estimated to be $11 \%$. While the real growth rate was $6 \%$, growth has barely exceeded population growth, which has been between $2.8 \%$ and $3 \%$. This trend is an indicator of the worsening poverty in Nigeria and precariousness of working bellow the PPC. Inflation has remained moderate thanks largely to a sustained increase in food production and the tight fiscal and monetary policy regimes of the federal government. The effects of increases in food production are lower cost of living and, consequently, lower consumer prices for manufactured products that depend on agricultural raw materials. Efforts at stimulating real sector activities have been dampened by high interest rates, poor infrastructure and import competition. (NBS, 2014)

Agriculture contributes to employment, food production, foreign exchange earnings and industrial inputs. In 2001, agriculture was about $41 \%$ of GDP; $60 \%$ of the workforce is employed in agriculture, predominantly smallholders (CBN, 2002). Nigeria has a total land area of 98.3 million hectares, of which only 71.2 million hectares are cultivable. Only 34.2 million hectares (about $48 \%$ of the cultivable area) are actually being cultivated, and less than $1 \%$ of the arable land is irrigated (FMARD, 2001). The modest growth of between $5.5 \%$ and $7.5 \%$ in the agricultural sector over the period 1999-2005 has been traced to the favourable weather conditions, while services and commerce expanded, following improvements in the purchasing power of consumers. Agricultural output has been increasing at a slow rate over the last several years, except in 2002 and 2003, when the sector grew at an average rate of about $7.5 \%$ per annum. The sector recorded moderate growth of $6.1 \%$ and $6.5 \%$ in 2004 and 2005 respectively. The growth of the staple crop production index has been oscillating between 3 and $3.6 \%$. All the major staples have recorded significant increases in output with the exception of maize. In spite of the decline in international market prices, cash crop production has been growing too, at least $3 \%$ for cocoa, coffee and rubber between 1999 and 2004. The index of livestock production in $1984-2001$ has been rising by at least $2.4 \%$ annually, while fisheries output has been rising by at least $3.6 \%$.( CBN, 2013)

Nigeria's Economic Potentials put her to be richly endowed with huge population/ human resources, vast natural resources, particularly oil and gas with oil reserves estimated at 36.2 billion barrels, at current extraction rates, proven and probable oil and gas reserves are estimated to last more than 50 years. Abundant mineral deposits such as tin, iron, limestone, coal, gold and sulphur, vast fertile soil and a very pleasant climate suitable for agriculture, population of over 150 million; the largest in Africa, access to sea and other valuable resources, Ayodele (2013).

Given the above facts and figure, Nigeria has a great potential to build a diversified sustainable and prosperous economy. Conversely, Nigeria has economic problems, her poverty situation is alarming though it records an impressive rate of economic growth which grew at an average 
7.6\% between 2003 and 2010(World Bank 2011), but this did not lead to sustainable development (Oladoyin, 2010)

According to CIA (2010), Nigeria's real GDP growth rate was $6.51 \%$ in 2005, it declined to $5.63 \%$ in $2006,5.0 \%$ in 2009 and rose to $6.4 \%$ in 2007 , before recording another fall to $6.1 \%$ in 2008. In 2010 it stood at 8.2\% (Abiola, 2012). Ajetomobi (2008) submits that both low grade and professional workers are more than $50 \%$ of unemployed citizens who had no vacancy for which they could be considered every year. When David Cameron admitted recently that the UK unemployment rate is disappointingly high and indicated his government desire to see faster growth in the economy, he took it for granted that when growth improves jobs are created. Leaders in developed and emerging economies have their eyes on the GDP growth figure as the leading indicator to decline in poverty incidence through reduced unemployment, increased household income and reduced inequality. BGL research and intelligence (2012).

In Nigeria however, despite the impressive economic growth over the last 10 years, unemployment and the incidence of poverty has worsened since 2004. The National Bureau of Statistics (NBS) released the poverty incidence figures for 2010 and that of 2011 for Nigeria. The figures suggested that the incidence of poverty in Nigeria worsened between 2004 and 2010. The report indicates that the number of Nigerians living below poverty line rose from $68.7 \mathrm{~m}$ to $112.5 \mathrm{~m}$ (63.7\% rise in poverty incidence) during the period while the population rose from $139.2 \mathrm{~m}$ to $158.6 \mathrm{~m}$ (13.9\% rise in population) over the same period. Earlier figures on unemployment in Nigeria corroborated this situation as the number of unemployed members of the labour force continued to grow from $12.3 \%$ in 2006 to $23.9 \%$ in 2011 . However, during the same period, Nigeria economy grew strongly at an average annual growth rate in excess of $6.6 \%$, making the country the 5th fastest growing economy in the World in 2010 at $7.87 \%$ real growth rate. (World Bank, 2013)

The above figure represents the paradox of growth in the face of poverty and inequality. It conflicts rational economic and social theories as well as historical trends. It highlights vividly the structural disequilibrium in the Nigerian economy which has sustained the key productive and highly employable sectors below potential while supporting consumerism and rent-seeking.

In the light of the above value judgment, this research work present the position of agricultural sector as a dominant tool for reviving the Nigerian Economy from being monoculture.

\section{GRAPHICAL ANALYSIS OF OIL AND AGRICULTURAL ISSUES IN NIGERIA}

Oil industry contributes to the Nigerian economy is in the attraction of FDI. Nigeria has attracted a lot of FDI particularly into the oil sector over the years and given the huge and bright potentials of this sector, it is likely that more new investments and reinvestments will be attracted. Several other channels through which oil has contributed to the Nigerian economy include provision of cheap and readily available source of energy, boosting of the foreign reserves and provision of employment (Odularo, 2008).

However, critics have contended that the direct effect of oil sector activity on non-oil growth in Nigeria is rather limited. It is argued that the oil sector being an enclave sector has very little 
linkages with the other sectors in the economy. The oil sector does not offer much opportunity for employment in Nigeria because it is more capital than labor intensive industry. This is the reason why the significant expansion of the sector over the years has not led to a similar increase in job creation. Indeed at present, total level of employment in the Nigerian oil industry (including employment by ancillary firms) as a percentage of total modern sectors' employment in the country currently stands at 1.3 per cent. This is extremely low when viewed in terms of the size of the sector. Moreover, oil-related outflows including imports of capital equipment, income repatriated to foreign investors and amortization of FDI liabilities have been highly substantial in the country.

Besides, it is contended that the high dependence of the country on oil has posed significant challenges to formulation and implementation of economic policies in the economy. As global price changes are difficult to be fully addressed by domestic macroeconomic policies; the oil price volatility has induced macroeconomic challenges in the economy. As an illustration, whenever there is a fall in the price of oil, counter-cyclical fiscal action is constrained due to lack of other sources of revenue. Oil price changes often make the exchange rate volatile thereby encouraging undue short-term capital flows. More often than not, government action to mitigate this volatility often results in pro-cyclical monetary stance. In general, as a result of the limited capacity of small non-oil sector in counteracting swings in oil prices in response to policy actions, the effectiveness of macroeconomic policy is often constrained. (Odularo, 2008)

\section{CRUDE OIL PRODUCTION}

The oil sector recorded an average daily production of 2.29 million barrels per day in the first quarter of 2013, Underperformance of crude oil output was attributed to: - Disruptions as a result of pipeline vandalization, Bunkering incidents and - force majeure declared by some oil companies.

- Improvements recorded in crude oil production in 2009-2010 seems to have been reversed (see the Table below)

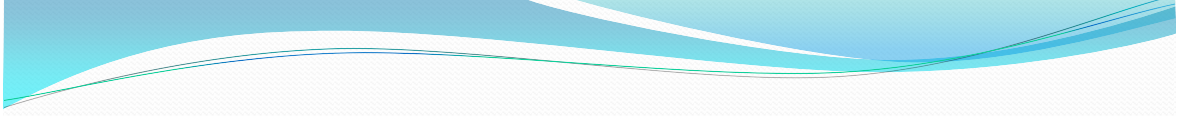

Table 2: Trend in Nigeria's Crude Oil Production

\begin{tabular}{|c|c|c|c|c|}
\hline Year & $\begin{array}{c}\text { Target } \\
(\mathrm{mbpd})\end{array}$ & $\begin{array}{c}\text { Actual } \\
(\mathrm{mbpd})\end{array}$ & $\begin{array}{c}\text { Variance } \\
(\mathrm{mbpd})\end{array}$ & $\begin{array}{c}\text { Variance } \\
(\%)\end{array}$ \\
\hline 2008 & 2.40 & 1.70 & -0.70 & -29.17 \\
\hline 2009 & 2.44 & 1.90 & -0.54 & -22.13 \\
\hline 2010 & 2.25 & 2.57 & 0.32 & 14.22 \\
\hline 2011 & 2.30 & 2.33 & 0.03 & 1.30 \\
\hline 2012 & 2.48 & 2.32 & -0.16 & -6.45 \\
\hline Q1 2013 & 2.526 & 2.29 & -0.236 & -9.34 \\
\hline April & 2.526 & 1.97 & -0.556 & -22.01 \\
\hline 2013 & & & & \\
\hline
\end{tabular}

Computed by Dr Olumide Ayodele 
Effects of lower crude oil output cushioned with the relative stability in international crude oil market price and the exchange rate of naira against the dollar The world crude oil price was well above the oil price benchmark of $\$ 80.00$ a barrel in the first half of 2013 (see Figure 1).

Figure 2: Bonny Light Crude Oil Price Movement, 2010-2013

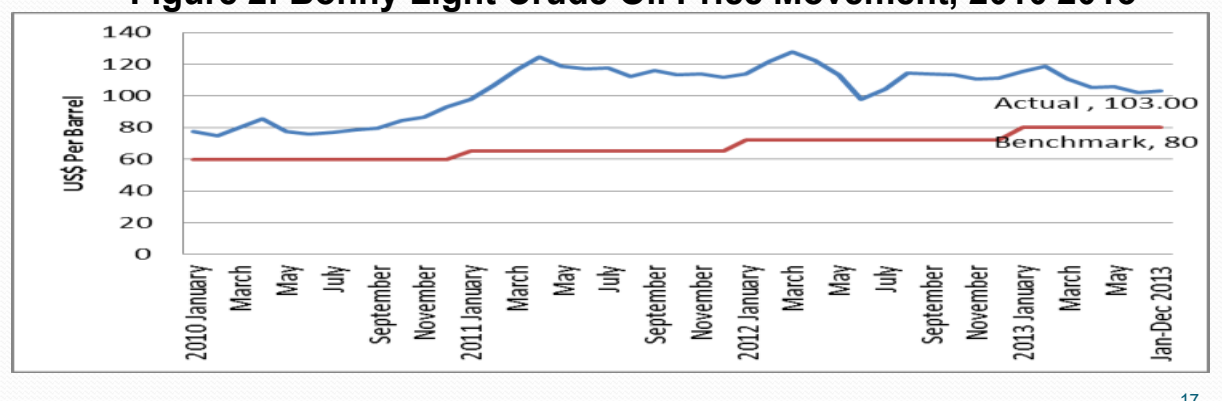

Computed by Dr Olumide Ayodele

\section{STRUCTURE OF THE NIGERIAN ECONOMY IN DIRECTION OF OIL AND AGRICULTURAL SECTOR}

The productive base of the Nigerian economy is based on primary production activities of agriculture and mining and quarrying

Misalignment between domestic production and consumption mono-cultural economic base (overwhelming dependence on crude oil exports) unbridled import dependence.

\begin{tabular}{|c|l|l|l|l|l|l|l|l|l|}
\hline \multicolumn{2}{|c|}{ Table 1: Structure of Exports and Government Revenue (per cent) } & \\
\hline & 1970 & 1975 & 1980 & 1985 & 1990 & 1995 & 2000 & 2005 & 2010 \\
Revenue & 100 & 100 & 100 & 100 & 100 & 100 & 100 & 100 & 100 \\
- Oil & 26.3 & 77.5 & 81.1 & 72.6 & 73.3 & 70.6 & 83.5 & 85.8 & 88.6 \\
$-\quad$ Non- & 73.7 & 22.5 & 18.9 & 27.4 & 26.7 & 29.4 & 16.5 & 14.2 & 11.4 \\
Oil & & & & & & & & & \\
Export & 100 & 100 & 100 & 100 & 100 & 100 & 100 & 100 & 100 \\
$\quad-$ Oil & 57.6 & 92.6 & 96.1 & 95.8 & 97.0 & 97.6 & 98.7 & 98.3 & 97.7 \\
- Non- & 42.4 & 7.4 & 3.9 & 4.2 & 3.0 & 2.4 & 1.3 & 1.7 & 2.3 \\
Oil & & & & & & & & & \\
\hline
\end{tabular}

Source: Central Bank of Nigeria 2011.

The accretion to foreign reserves resultant from the oil boom strengthened the domestic currency in the 1970s. The crisis from the glut resulted in the depletion of the external reserve, huge and increasing the performance of the manufacturing sector contribution to real GDP was 8 per cent from the early 1970 s to about 4.16 per cent in 2010, and oscillating to around 3.87 per cent in 2011. Building and construction witnessed a slow and sluggish growth rate with 5 per cent in the 1970s to about 2 percent in 2011. The structure of agricultural production in Nigeria shows dominance of crops production which accounts for $76.1 \%$ of the total in 1970 (Figure 2). The 
percentage drop slightly to about 61 per cent in 1980 which later rose to 83 per cent in 2000 with the highest growth rate in 2011 with 89 percent.

Computed by Authors

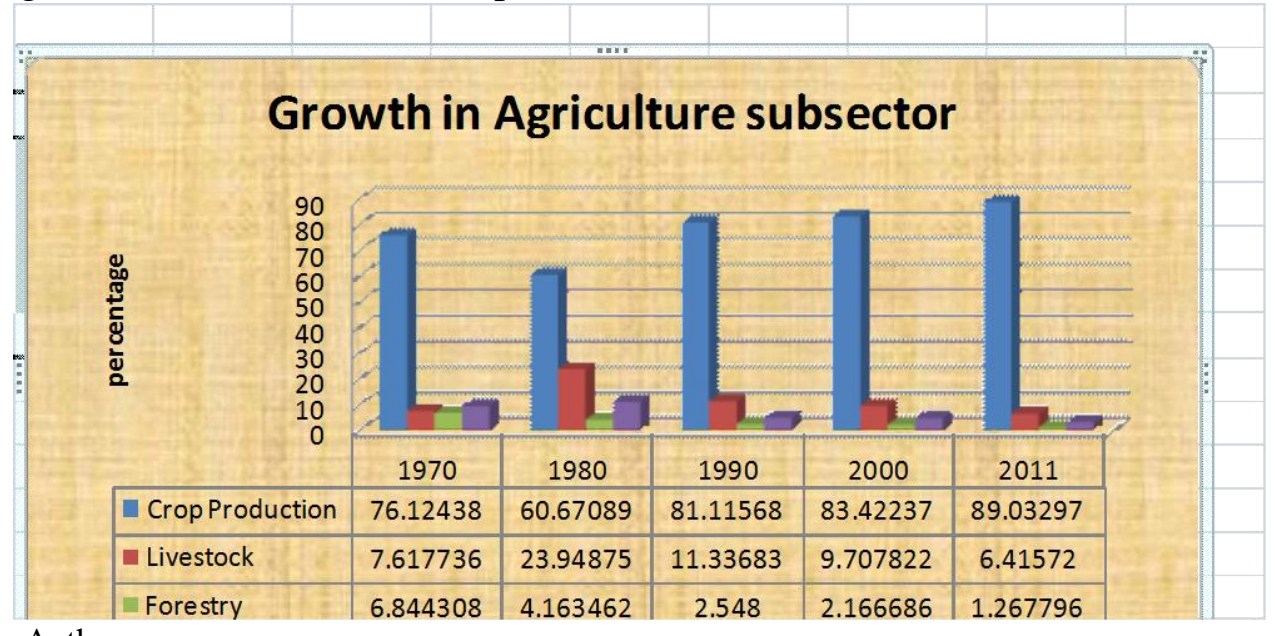

Crop production constitute the most important sector of the Nigerian economy in terms of contribution to output growth, real GDP share and as source of employment by providing livelihoods to most rural dwellers. This is followed distantly by livestock with a share of 7.6 percent in 1970 and drop to around 6.4 percent in 2011. The forestry subsector recorded a sharp decline from 6.8 per cent in 1970s to around 1.27 in 2011. The fishing component accounted for 9.4 per cent in 1970 and drop marginally to about 3.28 per cent in 2011 . The sporadic outbreak of avian influenza in the last six years constrained growth of the livestock sector.

Mining and quarrying sector comprising the oil and gas and solid minerals is heavily dominated by the oil and gas sector which account for 57 per cent share of the total nominal mining and quarrying in 1970 (Figure 3). The percentage contribution of solid minerals was at 4.38 in 1970 but fell to 1.84 per cent in 2011. The solid minerals recorded insignificant contribution despite rapid growth of solid minerals sub-sector. Overall, the oil and gas sector remains growthretarding in view of negative growth rates recorded in the sector in the past few years. Measures to address the Niger Delta crisis which have progressed significantly are expected to improve the fortunes of the sector. In addition to this, the search for alternative funding arrangements for joint venture activities could enhance the growth of the oil and gas sector.

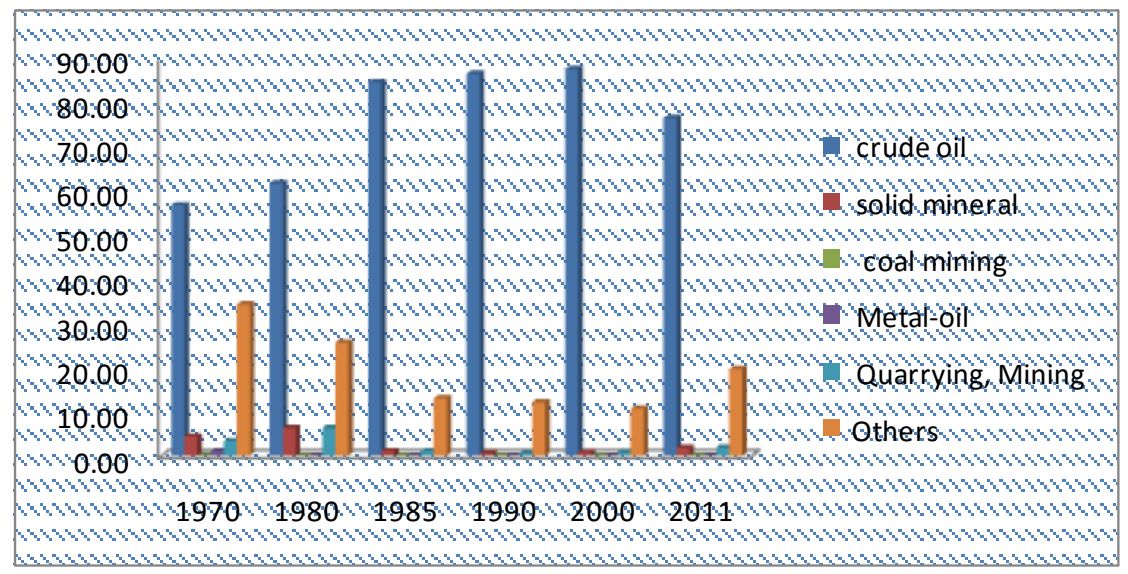

Source : Central bank of Nigeria Statistical Bulletin 2011. 
Available data from the National Bureau of Statistics (NBS) revealed that the quarterly Gross Domestic Product (GDP), in real terms stood at N182.12 billion, indicating growth of 6.17 per cent in the first quarter of 2012, against 7.13 and 7.68 per cent growth recorded in the corresponding quarter of 2011 and preceding quarter, respectively (Fig 6).

The slowdown in growth recorded in the first quarter resulted from the decreases in the relative contributions of agriculture, wholesale and retail and industry to $1.46,1.91$ and -0.31 in the current quarter from 2.31, 2.26 and 0.51 per cent recorded in the fourth quarter of 2011, respectively (Fig. 6).

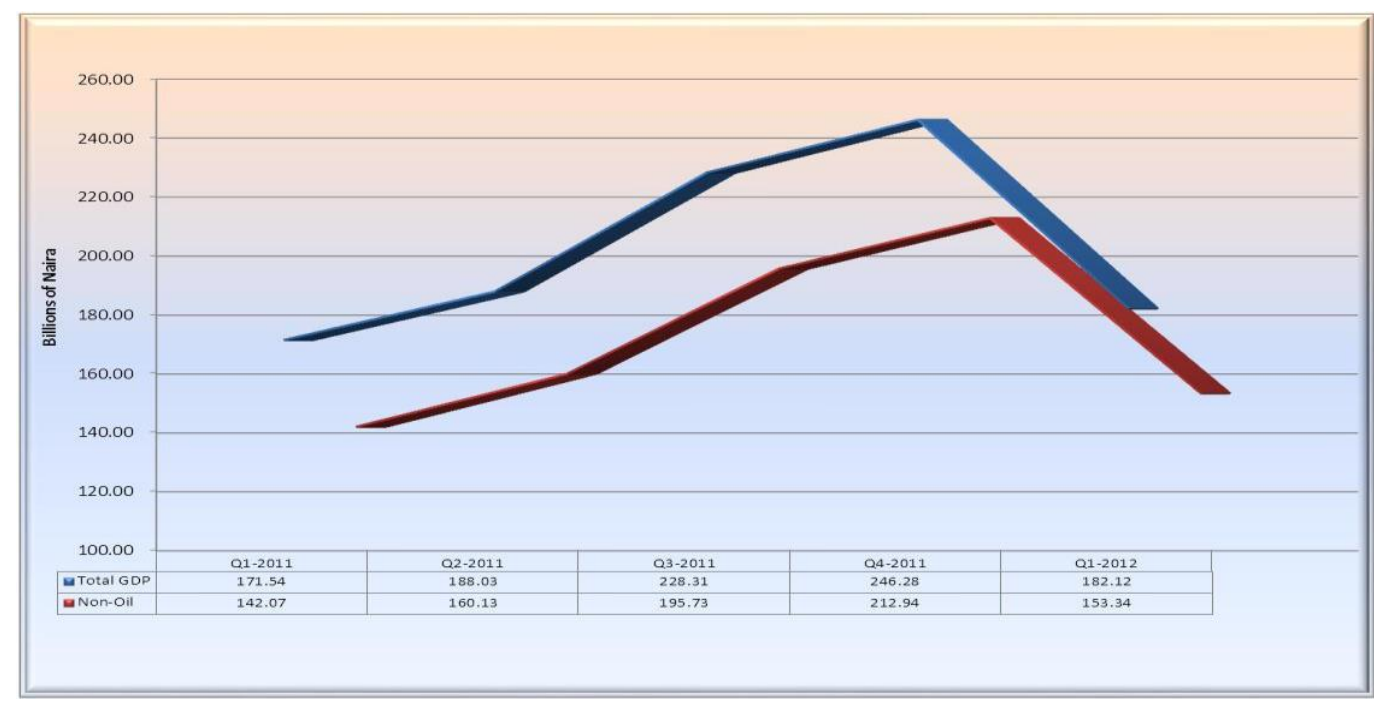

Figure 6: Movement in Quarterly Real GDP (Total and Non-Oil)

\section{SECTORAL ANALYSIS OF QUARTERLY REAL GDP}

Sectoral analysis showed that the agricultural output deteriorated as its relative contribution to the growth in real GDP decreased to 1.46 per cent in the first quarter of 2012 from 2.31 per cent in the preceding quarter. The decrease in activities in this sector was attributable to the fall in the relative contribution of crop and livestock production from 2.08 and 0.14 per cent in the fourth quarter of 2011 to 1.21 and 0.13 per cent in the current quarter (Fig. 3). The contributions of the fishing and forestry sub-sectors however, improved from 0.03 and 0.07 percent to 0.04 and 0.09 , respectively. Further analysis of the agricultural sector shows that the poor performance of the crop production sub-sector relative to the preceding quarter was mainly driven by the decrease in the relative contributions of all the major crops except maize which increased from 0.04 percent in the fourth quarter of 2011 to 0.09 percent in the current quarter. The relative contribution of Oil palm fruit however remained the same. 


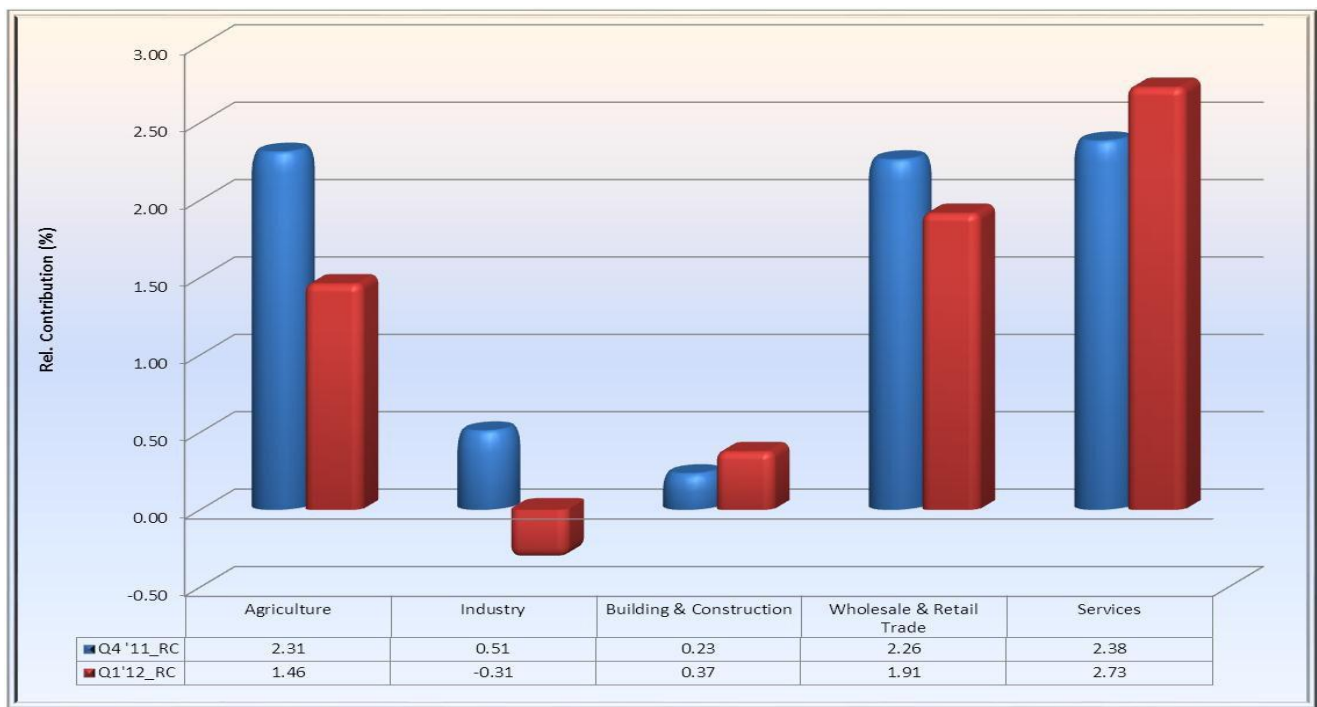

Source: Central Bank of Nigeria 2013.

Figure 7: Drivers of Quarterly Real GDP Growth in the First Quarter of 2012

Source: Central Bank of Nigeria 2013.

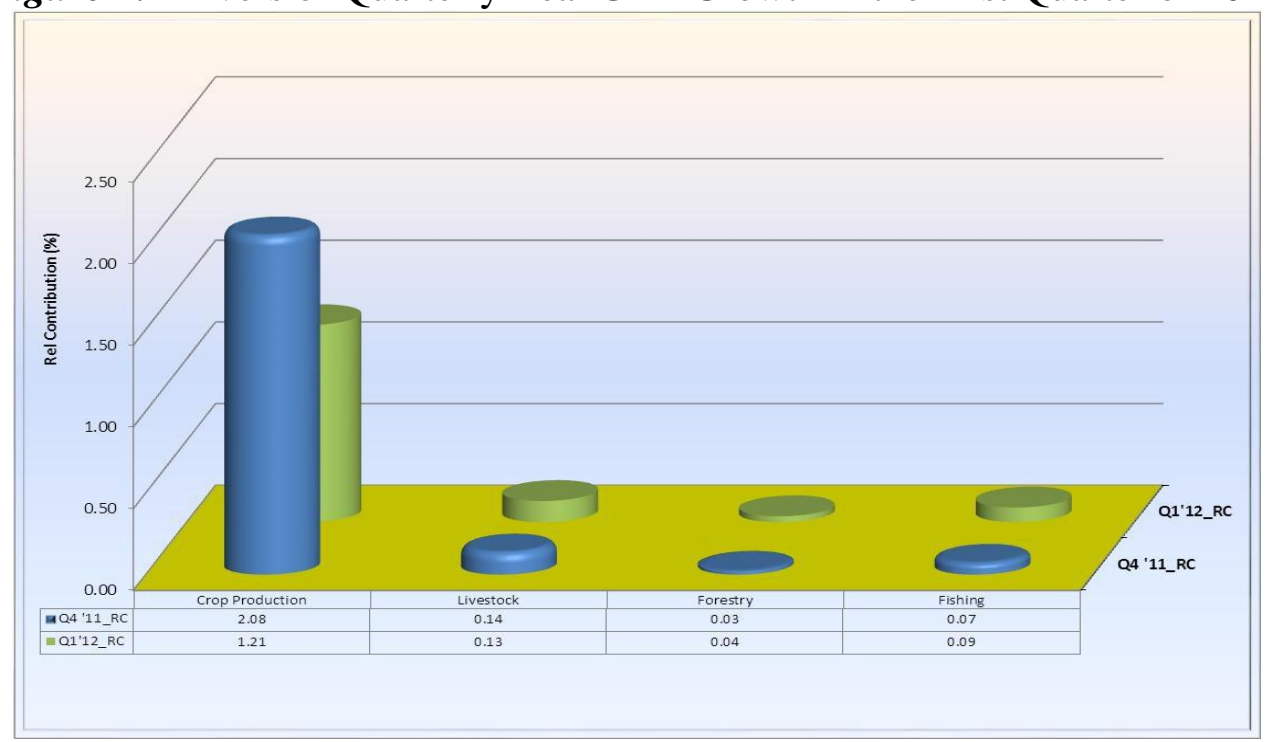

Figure 8: Agricultural Sector Drivers in Total GDP in the First Quarter of 2012

\section{NON-OIL REAL QUARTERLY GDP}

The non-oil real GDP growth stood at 7.93 per cent in the first quarter of 2012, indicating 1.14 percentage points below the 9.07 per cent growth achieved in the fourth quarter of 2011. The decrease in growth relative to the preceding quarter performance resulted largely from the decrease in the relative contributions of Agriculture, Industry and Wholesale \& Retail sectors from 2.70, 0.66 and 2.65 per cent in the preceding quarter to 1.76, 0.11 and 2.31 per cent in the current quarter under review, respectively. (Fig 9). The contributions of Services and Building Construction sectors increased from 2.79 and 0.27 per cent in the preceding quarter to 3.29 and 0.45 per cent in the current quarter, respectively. 


\section{SECTORAL ANALYSIS OF NON-OIL REAL QUARTERLY GDP}

The sectoral analysis showed that the agricultural sector relative contribution to the growth in real non-oil GDP decreased to 1.76 per cent in the first quarter of 2012 from 2.70 per cent recorded in the preceding quarter. The fall in the contribution of agriculture to non-oil real GDP was largely accounted for by Crop production whose contribution to non-oil real GDP growth fell from 2.43 percent in the fourth quarter of 2011 to 1.46 per cent in the current quarter. (Fig. 10)

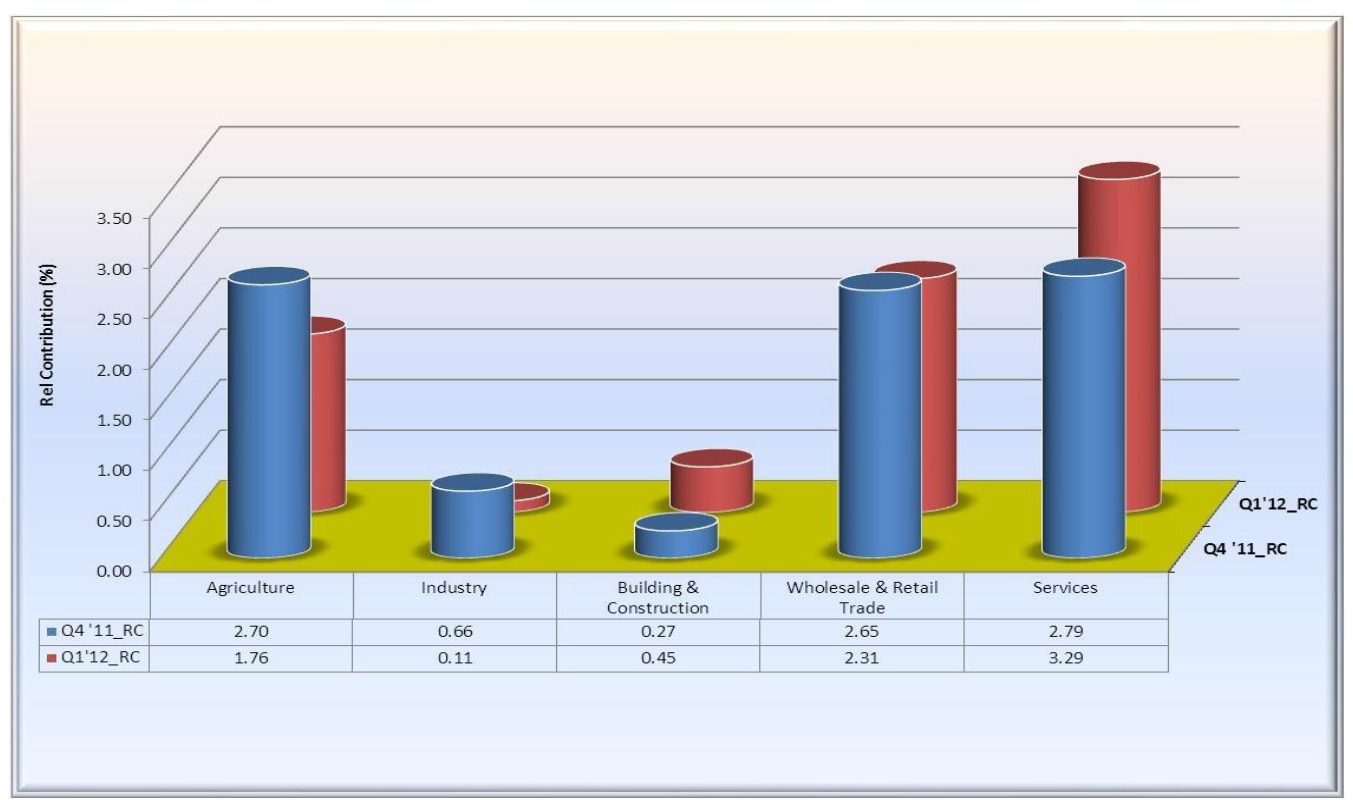

Source: Central Bank of Nigeria 2013.

Figure 4: Drivers of Quarterly Real Non-Oil GDP Growth in the First Quarter of 2012

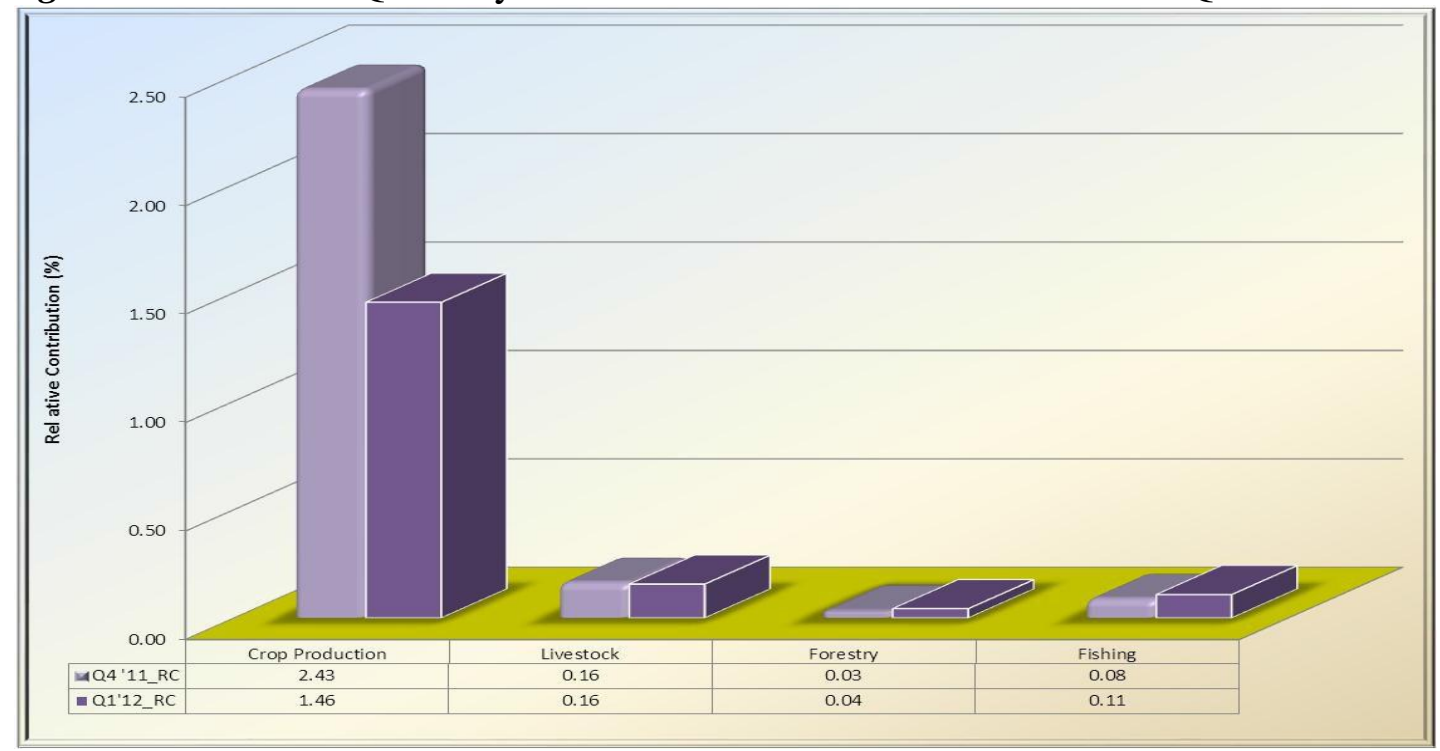

Source: Central Bank of Nigeria 2013. 
Growth and development in the oil rich economies could be enhanced through the market contribution from oil. The market contribution relates to the demand by oil sector for various inputs of goods and services provided by local sources. Generally, as a result of oil production, refining and distribution, there is tendency for oil sector-related services to spring up. These oil sector-related services will not only provide opportunity for employment but also serve as sources of earnings for the operators and ultimately contribute significantly to the productivity of the country, thou it employs less than $5 \%$ of the working population is also major source of export earning in Nigeria.

More so, Agriculture sector employ more than $65 \%$ of Nigerian populace and $87 \%$ of rural dwellers in the country it also contribute significantly to economic growth

\section{CONCLUSION AND POLICY RECOMMENDATIONS}

In this research work, we postulate agriculture to be a recipe from being Oil dependent economy. The aim of this study was to establish the fact that if Nigeria must break the vicious cycle of poverty and make their growth inclusive, agriculture sector must be their primary target. Generally, it is observed that crude oil production (domestic consumption and export) has had a positive impact on the economic growth in Nigeria. Consequently, based on the existing fact and figure, Nigeria growth is stranded at the top of the pyramid but failed to get to the middle talk less of the bottom of the pyramid where we have majority of populace employed. Therefore, any policy on poverty reduction strategies should put agricultural sector at the center planning. Thus, from the foregoing, we can conclude that 'the production of crude oil (domestic consumption and export) despite its positive effect on the growth of the Nigerian economy has not significantly improved the welfare of the Nigeria populace, due to many factors like misappropriation of public funds (corruption) and poor administration being not the major player in employment issues and not the sources of better welfare package for sustainable development of the country.

Based on the policy simulated from this research work, it is inevitable to provide a set of policy recommendation that would set Nigerian economy on the journey of becoming the major player in the world: -

1) The Nigerian National petroleum corporation (NNPC) should diversify its export baskets through downstream production; this will enhance the refined petroleum for exports.

2) The government should encourage more private company participation. So that better equipped refineries can be built and the cost of refining crude oil will reduce.

3) There should be direct plough back profit from Oil sector to Agriculture sector. Part of PTF fund should used to fund agricultural production which lacks adequate funding system;

4) There is urgent need for Nigeria to diversify their export market especially from oil product to agricultural product and high priority should be given to Africa; instead of concentrating on European countries and the United States which major focuses of our competitor. 
Government should give immediate attention to the procurement and subsiding of farm tools for easy development of the sector. Also, Irrigation system should be encouraged for better efficiency in production process. Finally, government should establish Companies that will convert agricultural primary product to non-perishable goods which stabilize the market price of farm product and motivate labour force to remain in the sector. Also, more agricultural banks should be established in the rural areas where farmers can be found. government should fight corruption by establishing institutions that will arrested and prosecute corrupt public office holders in the sector.

\section{REFERENCES}

[1] Abiola, B.A,(2012). "The Impact of poverty on Nigeria economic growth: in the new millennium.

[2] Ajetomobi J. O (2008) Education Allocation, Unemployment and Economy Growth in Nigeria: 1970-2004.

[3] Ayodele O. (2013) State of the Nigerian Economy Power Point Presentation Material.

[4] BGL Research \& Intelligence (2012), Infrastructure bonds and public investment deficit in Nigeria, BGL Research and Intelligence

[5] Central Bank of Nigeria (Statistical Bulletin) 2012 Publications, CBN, Abuja.

[6] Central Bank of Nigeria (Statistical Bulletin) 2011 Publications, CBN, Abuja.

[7] Central Bank of Nigeria (Statistical Bulletin) 2001 Publications, CBN, Abuja.

[8] Central Bank of Nigeria (Statistical Bulletin) 2013 Publications, CBN, Abuja.

[9] Central Bank of Nigeria (Various Issues) Annual Report and Statement of Accounts, CBN, Abuja.

[10] Central Bank of Nigeria "Annual Report and Statement of Account”. Various Issues.

[11] Dauda, R.O. (2010). Role of Human capital in economic Development: An Empirical study of Nigerian Case. Oxford: Oxford Business and Economics Conference Programme.

[12] Federal Ministry of Agriculture and Rural Development (FMARD) (2011). Presidential Brief on Agricultural Transformation Agenda, Presented 9th September, pp. 92

[13] National Bureau of Statistics (2010). Labour Force Survey March, 2009. Statistical News: Labour Force Statistics in Nigeria, ISSN 0794 - 1954, 476.

[14] Odularo G. O (2008) Crude Oil and the Nigerian Economic Performance. Oil and Gas Business.

[15] OECD publications Internet: www.sourceOECD.org

[16] Oladoyin, S.D. (2010) "Investment in Education and Economic Growth in Nigeria: An Empirical Evidence” International Research Journal of Finance and Economics. Issue 55. pp.216, 564.

[17] World Development Indicators database, 2010.

[18] World Bank, (2013): World Development Indicators, The World Bank, Washington, D.C 